\title{
Variations in lecturer task orientation and student perceptions of course effectiveness
}

\author{
ALLEN J. SCHUH \\ California State University, Hayward, California 94542
}

\begin{abstract}
The university professor's power position requires the professor to provide a high degree of structure, or task orientation, in courses taught according to the literature on leadership effectiveness. Goal clarity theory suggests that the structure will then be self-motivating, which in turn reinforces the professor's power position. It would follow that students' high effectiveness ratings for personalized system of instruction (psi) programs could be an artifact of the structuring of the course that the method requires. Different configurations of three courses $(\mathrm{N}=252)$ were used in a complex quasi-experimental design. Courses were taught by traditional lecture, with full program PSI, and traditional lecture with the high-PSI structuring only. Highly structured traditional lecture courses matched the complete PSI programs of instruction in achieving higher effectiveness ratings than those given to traditional lecture courses. If students' ratings of course effectiveness are the sole criterion of teaching effectiveness used by administrators, professors would be wise to structure their courses carefully and thoroughly. Results were significant beyond the .01 level.
\end{abstract}

In many academic settings professors are evaluated by their students' evaluations of them and of the courses they teach. Although using client ratings alone to evaluate teaching or training effectiveness can be criticized, the practice abounds as a major input to promotion and tenure decisions.

Fiedler's contingency model of leadership effectiveness suggests that a leader who finds himself in a situation with high legitimate power will promote group performance and be perceived as effective by the group by adopting a task-oriented leadership style (Fiedler, 1967, 1971, 1973).

The prime characteristic of the university environment that makes Fiedler's model relevant is the high power that the university has placed at the professor's disposal. The term "power" is used to mean the degree to which the position itself enables the leader to get the group members (students) to comply with and accept the leader's direction. Related terms are legitimate power and reward-and-punishment power.

But this high power only establishes a situation that then requires the professor to respond with a high degree of structure, or task orientation, if the leader is to be perceived as effective. Indeed, the theory specifically states that a leader in such a power position will only arouse anxiety if s/he does not demonstrate a high structure or task orientation for the group.

The highly structured task is one way of achieving

This study was partially supported by Grant 7251 to Dr. Allen J. Schuh from the Office of New Program Development and Evaluation, California State University and Colleges. Requests for reprints should be sent to Allen J. Schuh, Department of Management Sciences, California State University, Hayward, California 94542. goal clarity. Goal clarity refers to the degree to which tasks are clearly stated or known to group members. Goal clarity can be motivating in itself (Latham \& Yukl, 1975); it is one way of influencing member behavior by means of the organizational sanctions which can be imposed, and it reinforces position power.

To the extent that Fiedler's theory and the literature on goal clarity are useful to a university professor in performing his primary function, it should be found that the students' perceptions of course effectiveness should vary directly with the amount of task orientation that is imposed or removed in the courses the professor teaches.

\section{METHOD}

\section{Subjects}

The participants were students $(\mathrm{N}=252)$ enrolled in a total of 13 sections of courses in the business administration curriculum at California State University, Hayward. Three required courses were selected for study in this experiment: Organizational Behavior, Organization Theory, and Research Methods.

\footnotetext{
Design

There were eight cells in the experimental design. Four cells were designed to test the effectiveness of the experimental treatment of a high level of structure under two variations: with all of the embellishments of the personalized system of instruction, or Keller plan (Ryan, 1974), or with only the end-of-course criteria specified, with all other aspects of such a program abandoned. There were also four control groups intended to serve as standards against which the effects of the experimental treatment could be evaluated. All possible comparisons were present in the eight cells. Specifically, the Organization Theory course had a preexperimental control group, and experiniertal treatment group, which was the personalized system of instruction (PSI), and a follow-up treatment group which had only the high structure. The Research Methods course had a preexperimental control and a postexperimental control, with the PSI experimental treatment condition in between. The Organizational
} 
Behavior course had an experimental group with high structure only and a postexperimental control group.

\section{Procedure}

The traditional method of lecturing was used for the four control cells of the design. In these cells the only structure provided by the professor to the students was a course syllabus. It should be noted that this is the only structure currently required of the professor at this university, and the only structure the professor had given in 6 years of university-level teaching. In the four cells where extensive structure was introduced, there were two cells with all of the features of PSI. PSI includes far more than just increasing structure. But the rigid specification of end-of-course criteria is the first and one of the major goals of PSI. In both cells where PSI was used, all lectures were scripted, videotaped, and presented to the students under a demand schedule. Also included in PSI were detailed instructional objectives, frequent tests, student proctors, and an emphasis on subject mastery; the students determined their own progress. The additional cost of running PSI for these two cells of the design was approximately $\$ 800$ per student over usual administrative expenses. Naturally, university administrators would have a keen interest in knowing if students perceive the two conditions (PSI or high structure only) to be the same in ratings of course effectiveness.

All data were accumulated by department secretaries at the end of each term and were stored until the end of the experiment to prevent possible contamination or instructor influence on the data prior to completion of the study. The student judgments of overall effectiveness of the course were recorded on a 5-point scale. The students were instructed to evaluate the course in comparison to other courses they had taken. The author was the instructor of record for all course work completed in the experiment.

\section{RESULTS AND DISCUSSION}

The results are summarized in Table 1. Even with a cursory inspection, it is apparent that the cells with high structure received high course effectiveness ratings, while cells without the structure received low ratings. The ratings of effectiveness were high for structure with or without PSI or the Keller plan.

A two-way analysis of variance of the course (Organiation Theory or Research Methods) by amount of structure (traditional or PSI) showed that within level of structure differences were not significant $[F(1,81)=.17$, n.s.]. The interaction term was also not significant $[F(1,81)=.70$, n.s.]. Between the levels of structure, the difference in perceived effectiveness was highly significant $[F(1,81)=10.50, p<.01]$.

Taking the high level of structure away from the Organizational Behavior course led directly to a significant reduction in perceived effectiveness $[t(100)=5.39$,
Table 1

Student End-of-Term Effectiveness Evaluations by Course and Level of Structure

\begin{tabular}{|c|c|c|c|c|c|c|c|c|c|}
\hline \multirow{3}{*}{$\begin{array}{c}\text { Sequence } \\
\text { of Experi- } \\
\text { ment }\end{array}$} & \multicolumn{9}{|c|}{ Course } \\
\hline & \multicolumn{3}{|c|}{$\begin{array}{l}\text { Research } \\
\text { Methods }\end{array}$} & \multicolumn{3}{|c|}{$\begin{array}{c}\text { Organization } \\
\text { Theory }\end{array}$} & \multicolumn{3}{|c|}{$\begin{array}{c}\text { Organizational } \\
\text { Behavior }\end{array}$} \\
\hline & Mean & SD & $\mathbf{N}$ & Mean & SD & $\mathbf{N}$ & Mean & SD & $\mathrm{N}$ \\
\hline Stage 1 & 2.97 & 1.36 & 32 & 2.83 & 1.17 & 6 & & & \\
\hline Stage 2 & $3.63^{*}$ & .70 & 40 & $4.00 *$ & .82 & 7 & $3.53 * *$ & .91 & 40 \\
\hline Stage 3 & 2.81 & 1.08 & 37 & $4.07 * *$ & .98 & 28 & 2.50 & .99 & 62 \\
\hline
\end{tabular}

*The mean effectiveness rating for the personalized system of instruction.

**The mean effectiveness rating without the personalized system of instruction but with a high level of structure.

$p<.001]$. The Research Methods course also showed a significant reduction in perceived effectiveness when the level of structure was reduced $[t(75)=3.90, p<.001]$.

The implications to practice are apparent. An instructor need not invest considerable amounts of time or money to boost the student ratings of course effectiveness. Most instructors outline their courses anyway and have objectives for each lecture. The only essential extension is that this structure be made available to the students at the beginning of the term, a small extension indeed when one considers the potential impact on student ratings of course effectiveness and, in turn, the impact of the student ratings on the professor's career.

\section{REFERENCES}

Fiedler, F. E. A theory of leadership effectiveness. New York: McGraw-Hill, 1967.

FIEDLER, F. E. Validation and extension of the contingency model of leadership effectiveness: A review of empirical findings. Psychological Bulletin, 1971, 76, 128-148.

Fiedler, F. E. The contingency model: A reply to Ashour. Organizational Behavior and Human Performance, 1973, 9, 356-368.

LAtham, G. P., \& YUkI, G. A. A review of research on the application of goal setting in organizations. Academy of Management Journal, 1975, 18, 824-845.

RyAN, B. A. PSI: Keller's personalized system of instruction: An appraisal. Washington, D.C: American Psychological Association, 1974.

(Received for publication December 27, 1977.) 